\title{
FORMULATION AND EVALUATION OF IN VITRO TRANSDERMAL PATCH DICLOFENAC SODIUM USING CHITOSAN POLYMER AND POLYVINYL ALCOHOL CROSS-LINKED TRIPOLYPHOSPHATE SODIUM
}

\author{
ERNAWATY GINTING*, JULIA REVENY, SUMAIYAH \\ Department of Pharmacy, Universitas Sumatera Utara, Indonesia. Email: Ernawatyg@yahoo.com \\ Received: 06 February 2018, Revised and Accepted: 24 April 2018
}

ABSTRACT

Objective: The aim of this study was to investigate diclofenac sodium patches using chitosan (Ch) and polyvinyl (PVA) alcohol cross-linked tripolyphosphate sodium (TPP) to increased transdermal permeation of the drug from the matrix system across rabbit skin.

Materials and Methods: The chemical characterization of diclofenac sodium was done by ultraviolet-visible spectrophotometry. Formulation of diclofenac sodium patches using solvent evaporation method with cross-link technique. Evaluation of physical character of the film includes organoleptic observation, weight test, thickness, \% moisture absorption, fold resistance, interaction between materials used Fourier transform infrared (FTIR), and active substance levels. The drug release was determined using Franz diffusion cells in phosphate buffer (pH 7.4).

Results: The result of physiochemical parameters of the transdermal patch were found satisfactory. Formula F1, F2, F3, and F4 produce patches with fine texture, F5 and F6 formulas produce patches with coarse texture. Formula F1, F2, F5, and F6 are flexible and fulfill the multiplier test requirements, while the F3 and F4 formulas are not flexible and do not meet the multiplier test requirements. The patch weight, thickness, and drug content were uniform. The release of patches with following the zero-order release. The optimal formula with the total sodium diclofenac released as much as $17.89 \mu \mathrm{g}$, the release flux of $89.42 \mu \mathrm{g} / \mathrm{cm}^{2} / \mathrm{h}$ of permeation time of $10 \mathrm{~h}$ and the moisture absorption rate of 1.07 \pm 0.193 . The FTIR data of rabbit skin indicated $\mathrm{Ch}$ and PVA alcohol cross-linked TPP increase transdermal permeation of diclofenac sodium in the stratum corneum.

Conclusion: The diclofenac sodium can be prepared by cross-linked method, resulted in a better discharge profile.

Key words: Diclofenac sodium, Chitosan, Polyvinyl alcohol, Tripolyphosphate sodium, Glycerin, Release kinetics.

(C) 2018 The Authors. Published by Innovare Academic Sciences Pvt Ltd. This is an open access article under the CC BY license (http://creativecommons. org/licenses/by/4. 0/) DOI: http://dx.doi.org/10.22159/ajpcr.2018.v11i8.25145

\section{INTRODUCTION}

The transdermal patch is designed to be able to deliver the drug in a controlled manner directly to the blood vessels [1]. The transdermal advantages such as to avoid absorption problem in the gastrointestinal tract, prevent the first cross effect, may be the choice for drugs not to be orally administered, may control the drug [29]. Transdermal can be formulated in ointment, cream, gel emulsion, and patch form [5]. The controlled delivery of drugs in the blood vessels can be achieved through the matrix system [36]. The basic components of the matrix system consist of polymers [7], drugs, enhancers, and other excipients [34]. Variations of polymer compositions, enhancers, and plasticizers will result in different release and permeation profiles [37]. The polymer in the matrix system will control the release rate of the drug from the patch matrix [3].

This study used diclofenac sodium as a test model of in vitro release and permeation using rabbit skin [33]. Diclofenac sodium includes nonsteroidal anti-inflammatory drugs that act by inhibiting cyclooxygenase in a non-selective manner, resulting in inhibition of prostaglandin synthesis, which is a pain mediator [2]. The diclofenac sodium has a half-life of 1-2 h so that it is orally administered in a few times, leading to adverse side effects on the stomach and reducing patient compliance [4]. Stratum corneum is a limiting factor in the speed of percutaneous drug taking [23]. The diclofenac sodium has a fairly high lipophilicity with a low partition coefficient value, octanol/water $\log \mathrm{P}$ at $25^{\circ} \mathrm{C}$ that is 4.17 causing low diclofenac sodium permeability [46].

This study used chitosan (Ch) polymer excipients, tripolyphosphate sodium (TPP), alcohol polyvinyl (PVA), and glycerol plasticizer [35]. Ch is widely used because it has the characteristics of biocompatibility, non- toxic, and antimicrobial [13]. Ch and alcohol PVA that are hydrophilic will increase patch permeability and drug diffusion [12,32]. Ch with alcohol PVA produces cross-linking hydrogels with good swelling activity. The combination of $\mathrm{Ch}$ and alcohol PVA anhydrous maleic cross-links by alprazolam model resulted in patches with physical characteristics, permeability, and release profiles [29]. Penetration test of Ch cross-linked tripolyphosphate sodium (TPP) with diclofenac diethylamine model showed 30-min cross-link time yielding the best permeation through mouse skin membrane [39]. The combination of $\mathrm{Ch}$ and alcohol PVA cross-linked tripolyphosphate sodium using bovine serum albumin produced a controlled release film that could be characterized by Fourier transform infrared spectroscopy (FTIR), scanning electron microscope (SEM), and release test. Studies on the use of glycerin plasticizer using $\mathrm{Ch}$ - alcohol PVA polymer resulted in a controlled patch [52].

\section{MATERIALS AND METHODS}

\section{Materials}

Chemicals

The materials used in this study were diclofenac sodium (Kimia Farma, Indonesia), PVA alcohol, TPP, Ch, glycerin, acetic acid, hydrogen phosphate sodium, bromide potassium, and chloride potassium (Merck).

\section{Animals}

Adult male New Zealand albino rabbits (1.5-2 kg) were supplied by the Animal House of Pharmacology, Laboratory of Pharmacy Department at Universitas Sumatera Utara was inhabited under standard laboratory condition with proper diet. The animal were accepted after the proposed 
study was approved by the Animal Research Ethics Committees (Komite Etik Penelitian Hewan FMIPA, Universitas Sumatera Utara), Government of Indonesia bearing the number 530/KEPH-FMIPA/2017.

\section{Methods}

Procedure for preparation patch of natrium diclofenac

The transdermal patch of diclofenac sodium is prepared by solvent evaporation technique, using a combination of Ch-PVA-TPP polymer and glycerine plasticizer [27]. The formula prepared by mixing an $8 \%$ PVA solution and $2 \% \mathrm{Ch}$ with ratio that has been determined, adding a diclofenac sodium and glycerin solution, stirring with a magnetic stirrer until a composite film is formed, the film is cast into the mold, then dried in a $40^{\circ} \mathrm{C}$ oven for $48 \mathrm{~h}$. To make the cross-linked film membrane formed soaked in $1 \%$ sodium tripolyphosphate solution with time 10 and $20 \mathrm{~min}$, the film was then dried in a $40^{\circ} \mathrm{C}$ oven for $24 \mathrm{~h}$. The finished film is transferred to plaster [26].

\section{Transdermal patch formulation}

The composition of transdermal patch formulation can be seen on Table 1.

\section{Evaluation of transdermal patch characteristics}

\section{Physical appearance}

The quality of transdermal patches can be physically evaluated for color, clarity, and texture of the surface.[11,21,44]

\section{Uniformity of weight}

The test of matrix weight of each formula is done by weighing the matrix of each formula, then calculated the average weight [14]

\section{Thickness uniformity}

The thick patch measurements employed a slider and were performed on three different sides of the matrix on each matrix patch formulas [14].

\section{Percentage moisture uptake}

The weighed patch is then inserted in the desiccator at $30^{\circ} \mathrm{C}$ for $24 \mathrm{~h}$. Furthermore, the patch is taken out from the desiccator and weighed again. Percent of moisture absorption is calculated using the following formula $\%$ power [11].

\section{Folding endurance}

This test is performed to determine the elasticity and fragility of transdermal patches [7]. Testing of resistance to folding is done by folding the patch repeatedly in the same position until the patch is broken. The number of folds is considered to be the value of resistance to folding [11].

\section{Observation of patch morphology}

Ch - PVA-TPP solution containing diclofenac sodium is disonified for 1 min to produce a good particle disperse [32]. One drop of the solution is dispersed into carbon-coated copper gird which is then dried at room temperature for SEM photography analysis. The SEM-5800 LV instrument was used to study the surface morphology of the diclofenac sodium patches with high vacuum and a high voltage of $15.00 \mathrm{kv}$ condition [31].

\section{Examination with FTIR [45]}

The diclofenac sodium patch is made in the form of a $\mathrm{KBr}$ pellet. How, matrix patch containing diclofenac sodium and without diclofenac sodium mixed with $10 \mathrm{mg} \mathrm{KBr}$ in the mortar, then crushed to homogeneous [44]. The mixture is forged with hydraulic pressure so that a transparent disc is obtained. The spectrum was measured using IR spectroscopy at a wavelength of $400-4000 \mathrm{~cm}^{-1}$ [43]

\section{Rabbit skin preparation and in vitro permeation study}

Permeation study [21]

Preparation of standard solution

$100 \mathrm{mg}$ diclofenac sodium was weighed, then put into a $100 \mathrm{ml}$ flask, then dissolved in phosphate buffer pH 7.4 to $100 \mathrm{ml}$ with sonification aid obtained $1000 \mu \mathrm{g} / \mathrm{ml}$ standard solution (LIB I). Standard standard solution of $1000 \mu \mathrm{g} / \mathrm{ml} 10 \mathrm{ml}$ dipipet then put $100 \mathrm{ml}$ papier flask added phosphate buffer solution $\mathrm{pH} 7.4$ to $100 \mathrm{ml}$ so obtained 100 $\mu \mathrm{g} / \mathrm{ml}$ concentration (LIB II). The solutions were aspirated by pipette, respectively, $0.2,0.4,0.6,0.8,1.0,1.2,1.4,1.6,1.8$ and $2.0 \mathrm{ml}$ were then inserted into the flask $10 \mathrm{ml}$ and inserted phosphate buffer to obtain concentration $2-20 \mu \mathrm{g} / \mathrm{ml}$. The absorption is measured at the maximum wavelength obtained.

\section{Drug content uniformity}

The $1.5 \mathrm{~cm}$ film was cut into small pieces, then put into a $100 \mathrm{ml}$ buffer $(\mathrm{pH} 7,4)$ and shaken with a magnetic bar for $5 \mathrm{~h}$ then it was ultrasonified for 15 min then filtration. The result of filtration measured the content of active substance with spectrophotometer at $\lambda 228 \mathrm{~nm}[14]$.

\section{Preparation phosphate-buffered saline (PBS) solution}

PBS solution was made from $\mathrm{KCl}$ of $0.1 \mathrm{~g}, \mathrm{KH} 2 \mathrm{PO} 4$ of $0.1 \mathrm{~g}, \mathrm{NaCl}$ of $4 \mathrm{~g}$, and $\mathrm{Na}_{2} \mathrm{HPO}_{4} \cdot \mathrm{H}_{2} \mathrm{O}$ of $1.08 \mathrm{~g}$. The materials were dissolved in $250 \mathrm{ml}$ of $\mathrm{CO}_{2}-$ free distilled water and homogenized using a magnetic stirrer in a $500 \mathrm{ml}$ glass. The $\mathrm{pH}$ of the solution is adjusted to reach 7.4 with $1 \mathrm{M} \mathrm{NaOH}$ solution using $\mathrm{pH}$ meter. The solution was then transferred to a $500 \mathrm{ml}$ measuring flask and $\mathrm{a}_{2}$-free aquadest was added to the limit marker.

\section{Rabbit skin preparation}

Rabbits used in the study were male rabbits weighing 1.5-2 kg. Rabbits are sacrificed with diethyl ether, and then, the hair on the skin of the back is cut with a shaver without damaging the stratum corneum layer. The rabbit's skin is separated; the fatty layers still attached are removed and then circled in accordance with the size of the diffusion cell. The skin used was measured in thickness, and before use, it was immersed in phosphate buffer $\mathrm{pH} 7.4$ for $1 \mathrm{~h}$ and stored at $4^{\circ} \mathrm{C}$. Leather can be used within $24 \mathrm{~h}$.

\section{Preparation of sample solution}

The transport test was carried out using a modified vertical type Franz diffusion cell. The donor portion contains a transdermal patch of diclofenac sodium [6]. The donor and acceptor compartment separator membrane is the rabbit's skin. The membrane is placed between the donor compartment and the acceptor compartment with the dermis side facing the acceptor compartment. The acceptor compartment contains a PBS of pH 6.8 of $15 \mathrm{~mL}$ and stirred with a continuous magnetic stirrer at $37 \pm 1^{\circ} \mathrm{C}$. The observation was conducted for $24 \mathrm{~h}$ and the samples were taken at hour to $1,2,4,6,8,10,12$, and 24 every $1 \mathrm{~mL}$ sampling was done by adding phosphate buffer $\mathrm{pH} 6.8$ as much as $1 \mathrm{~mL}$. Samples were stored in closed flaccon containers and diclofenac sodium content was determined by ultraviolet-visible spectrometric instrument and determined drug release kinetics $[14,16]$

\section{RESULTS AND DISCUSSION}

\section{Evaluation of transdermal patches}

The observed results of various physicochemical parameter of diclofenac sodium transdermal patches are shown in Table 2. The values of weight, thickness, and drug content were found to be uniform having an almost low value of standard deviation [8]. The result of evaluation of folding endurance was indicated F1, F2, F5, and F6 patch were the ability to withstand rupture and qualified the multiplier test.

\section{Scanning electron microscope}

The homogeneity of patch surface was determined using scanning electron microscope [53]. The cross-linked produced a smooth patch with different levels of density and homogeneity. The result of evaluation of patch morphology can be seen at Fig. 1.

\section{Drug excipient compatibility study}

\section{FTIR spectroscopy}

The diclofenac sodium spectrum shows the spectral peaks in regions 3402.43 and $3248.13 \mathrm{~cm}^{-1}$ in the presence of the $\mathrm{NH}$ group, as can be seen in Fig. 2 and Table $3 \mathrm{~A}$ Ch spectrum, producing a peak spectrum at 
Table 1: The composition of the diclofenac sodium patch

\begin{tabular}{llllll}
\hline Formula & Cross-linked time & Glycerin ( \%) & TPP (\%) & Ch-PVA (2 and 8\% ) & Diclofenac sodium ( mg ) \\
\hline F1 & 10 & 5 & 1 & $30: 70$ & 20 \\
F2 & 20 & 5 & 1 & $30: 70$ & 20 \\
F3 & 10 & 5 & 1 & $50: 50$ & 20 \\
F4 & 20 & 5 & 1 & $50: 50$ & 20 \\
F5 & 10 & 5 & 1 & $70: 30$ & 20 \\
F6 & 20 & 5030 & 20 \\
\hline
\end{tabular}

TPP: Tripolyphosphate sodium, Ch: Chitosan, PVA: Polyvinyl

Table 2: Drug content and physical parameters of different formulation of patch

\begin{tabular}{|c|c|c|c|c|}
\hline Formulation code & Uniformity of weight (mg) & Film thickness (mm) & Folding endurance & $\%$ Drug content \\
\hline $\mathrm{F} 1$ & $172 \pm 0.574$ & $0.253 \pm 0.0010$ & 631 & $95.08 \pm 0.626$ \\
\hline F2 & $177 \pm 0.812$ & $0.262 \pm 0.0066$ & 631 & $96.37 \pm 0.102$ \\
\hline F3 & $184 \pm 0.812$ & $0.274 \pm 0.0014$ & 8 & $97.54 \pm 0.376$ \\
\hline $\mathrm{F} 4$ & $181 \pm 1.000$ & $0.266 \pm 0.0016$ & 8 & $95.74 \pm 0.359$ \\
\hline F5 & $184 \pm 0.812$ & $0.266 \pm 0.0016$ & 724 & $97.54 \pm 0.376$ \\
\hline F6 & $185 \pm 1.153$ & $0.267 \pm 0.0010$ & 722 & $97.46 \pm 0.343$ \\
\hline
\end{tabular}

Table 3: In vitro cumulative percentage of diclofenac sodium release

\begin{tabular}{llllllll}
\hline No & Time & F1 & F2 & F3 & F4 & F5 & F6 \\
\hline 1 & 10 & 4.99 & 3.53 & 4.25 & 1.17 & 5.42 & 1.48 \\
2 & 20 & 10.11 & 7.58 & 10.49 & 2.4 & 11.43 & 3.16 \\
3 & 30 & 15.52 & 12.21 & 15.63 & 5.31 & 17.7 & 5.96 \\
4 & 60 & 21.83 & 17.22 & 21.9 & 8.2 & 24.57 & 7.51 \\
5 & 120 & 27.72 & 23.46 & 28.73 & 11.31 & 31.81 & 10.09 \\
6 & 180 & 34.6 & 30.37 & 35.97 & 14.78 & 39.3 & 12.9 \\
7 & 240 & 42.27 & 37.82 & 43.78 & 18.2 & 47.07 & 16.34 \\
8 & 300 & 50.35 & 45.62 & 52.23 & 21.21 & 55.47 & 19.11 \\
9 & 360 & 58.81 & 54.06 & 62.82 & 23.1 & 64.01 & 22.89 \\
10 & 420 & 68.12 & 63.97 & 70.22 & 25.68 & 73.24 & 26.93 \\
11 & 480 & 77.62 & 74.88 & 77.99 & 28.69 & 82.64 & 31.13 \\
12 & 540 & 85.94 & 84.24 & 87.91 & 30.15 & 91.8 & 34.36 \\
13 & 600 & 94.07 & 92.82 & 95.76 & 32.69 & 99.81 & 37.24 \\
\hline
\end{tabular}

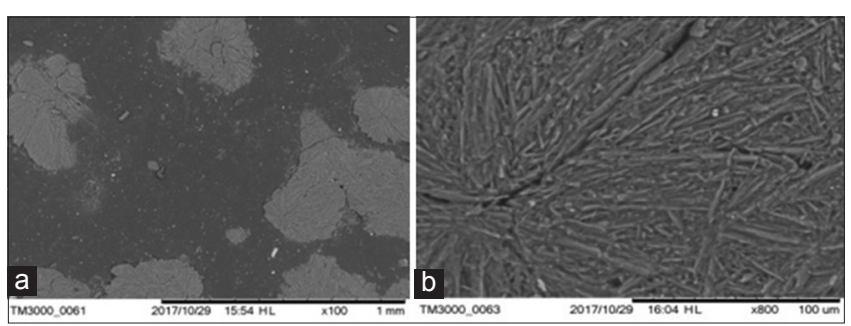

Fig. 1: The morphology of patch sodium natrium diclofenac at $\times 100(a)$ and $\times 800(b)$

$3437.15 / \mathrm{cm}$ in the presence of the $\mathrm{NH}_{2}$ and $\mathrm{OH}$ groups in the $1600.92 /$ $\mathrm{cm}, 1666.50 / \mathrm{cm}$ region in the presence of $\mathrm{C}=0$.

Observation of FTIR PVA shows peak spectrum at 3375.43/cm region with the presence of $\mathrm{OH}$ group. FTIR observations of TPP showed peak spectrum at $3430.03 / \mathrm{cm}, 3383.14 / \mathrm{cm}, 3217.27 / \mathrm{cm}$, and $1157.29 / \mathrm{cm}$. Ch interaction TPP resulted in a shift of absorption peak at $1549.02 / \mathrm{cm}$, $1481.33 / \mathrm{cm}$, and $1134 / \mathrm{cm}$. Peakat $3549.02 / \mathrm{cm}$ indicated no interaction between sodium diclofenac and the excipient polymer.

\section{Permeation study}

All the six formulations were subjected to in vitro permeation studies across rabbit skin for establishing the permeation parameters $[15,19]$. The results of permeation study were shown on Table 3 and Fig. 3. According to the penetration test, cumulative value of penetrated sodium diclofenac was found highest in F5 (cumulative \% 99.81 time

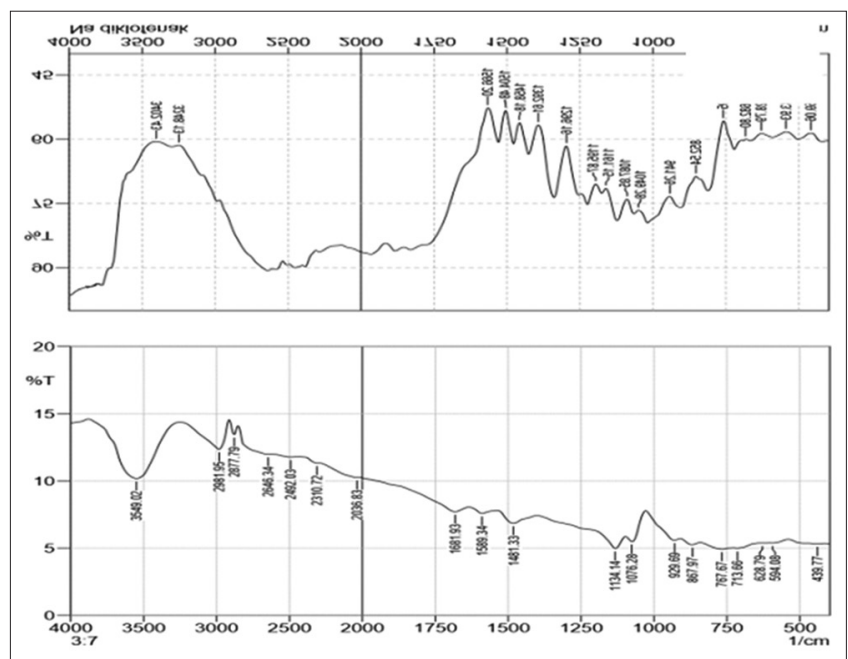

Fig. 2: Infrared spectra of pure of sodium diclofenac and patch sodium diclofenac

$10 \mathrm{~h}$ ), followed by F3, F1, and F2. Cumulative value of penetrated sodium diclofenac was found lowest in $\mathrm{F} 6$ and $\mathrm{F} 4$ with cross-linked time $20 \mathrm{~min}$. The release of patches with formulas was following zero-order release (Table 4). Permeation study was showed F1, F3, and F5 with cross-linked time $10 \mathrm{~min}$ has bigger \% cumulative and better release than F2, F4, and F6 with cross-linked time 20 min.

\section{CONCLUSION}

In the present study, various formulation of transdermal sodium diclofenac patches were prepared using cross-linked method of Ch polymer, polyvinyl alcohol, and tripolyphosphate sodium. This research showed that the formulation of transdermal diclofenac sodium patches using cross-linked method with cross-linked time of $10 \mathrm{~min}$ has better profile release than cross-linked time of $20 \mathrm{~min}$. Formulation of transdermal sodium diclofenac patches using crosslinked method needed optimal drying to make good characteristic and profile release.

\section{AUTHOR'S CONTRIBUTION}

The first author has carried out the research and provided study conception. The second and third authors have provided study conception, the design of work, drafting of the manuscript, and critical revision. 


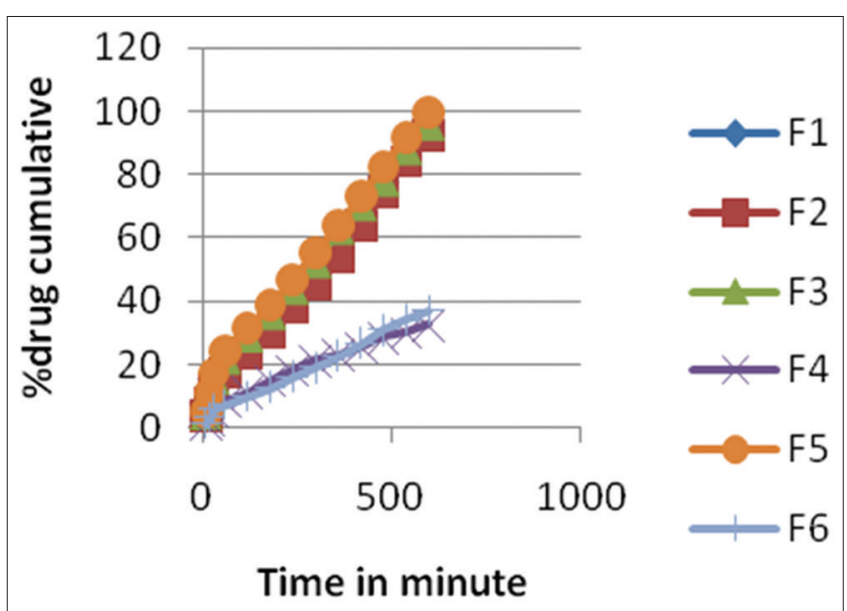

Fig. 3: In vitro profile permeation of various patches

Table 4: $\mathbf{R}^{2}$ value from of zero order, Higuchi and Korsmeyer plot

\begin{tabular}{lllllll}
\hline & F1 & F2 & F3 & F4 & F5 & F6 \\
\hline Orde nol & 0.994 & 0.994 & 0.993 & 0.973 & 0.991 & 0.994 \\
$\begin{array}{l}\text { Korsmeyer- } \\
\text { Peppas }\end{array}$ & 0.982 & 0.982 & 0.977 & 0.973 & 0.979 & 0.974 \\
Higuchi & 0.965 & 0.95 & 0.971 & 0.996 & 0.973 & 0.959 \\
\hline
\end{tabular}

\section{CONFLICT OF INTEREST}

The authors declare that there is no conflict of interest regarding the publication of this article.

\section{REFERENCES}

1. Agoes G. Sistem Penghantaran Obat Pelepasan Terkendali. $2^{\text {nd }}$. Bandung: Penerbit ITB; 2008. p. 373.

2. Agustin R, Ratih H. Dissolution Profile of Sustained Release Tablet of Diclofenac Sodium Using Metolose 90 Sh 4000. J Sains Farm Klin 2015;1:176-83.

3. Alexander A, Dwivedi S, Ajazuddin, Giri TK, Saraf S, Saraf S, et al. Approaches for breaking the barriers of drug permeation through transdermal drug delivery. J Control Release 2012;164:26-40.

4. Allen L, Ansel HC. Ansel's Pharmaceutical Dosage Forms and Drug Delivery Systems. Philadhelpia: Lippincott Williams \& Wilkins; 2013. p. 295 .

5. Ansel HC. Pengantar Bentuk Sediaan Farmasi. Edisi Keempat. Jakarta: UI-Press; 2005. p. 176-81.

6. Banakar UV, Pharmaceutical Dissolution Testing. New York: Marcel Dekker, Inc. 1991. J Pharm 1992;151:26-32.

7. Barhate SD, Potdar MB. Formulation of transdermal patch of Carvedilol by using novel polymers. Pharmacia 2012;2:185-9.

8. Bartosova L, Bajgar J. Transdermal drug delivery in vitro using diffusion cells. Curr Med Chem 2012;19:4671-7.

9. Bazigha K, Rasool A, Eman F, Fahmy A, Sadan S. Development and evaluation of ibupropen transdermal gel formulation. Trop J Pharm Res 2010;9;355-63.

10. Bhattarai N, Gunn J, Zhang, M, Chitosan hydrogels for controlled, localized drug delivery. Adv Drug Deliv Syst 2010;62:83-99.

11. Bhavani PP, Kumar PR, Shankar RK, Santosh T. Formulation and evaluation studies on transdermal dosage forms of diclofenac sodium. World J Pharm Pharm Sci 2015;4:1043-63.

12. CanAS, Erdal MS, Gungor S, Ozsoy Y. Optimization and characterization of chitosan film for transdermal delivey of ondansentron. Molecules 2013; 18:5455-71.

13. Cheung RC, Ng TB, Wong JH, Chan WY. An update potential biomedical and pharmaceutical application. Mar Drug 2013;13:5156.

14. Das A, Ahmed AB. Formulation and evaluation of transdermal patch of indomethacin containing of pathcouli oil as natural penetration enhancer. Asian J Pharm Clin Res 2017;10:320-5.
15. Dash S, Murthy PN, Nath L, Chowdhury P. Kinetic modeling on drug release from controlled drug delivery system. Acta Pol Pharm 2010;67:217-23.

16. Devissaguet J, Aiache JM. Farmasetika 2 Biofarmasi. $2^{\text {nd }}$ ed. Surabaya: Widji Soerarti. Airlangga University Press; 1993. p. 443-58, 172.

17. Flyn GL, Stewart B. Percutaneus drug penetration choose candidates for transdermal drug development. Drug Dev Res 1988;13:169-85.

18. Fox SC. Remington Education Pharmaceutics. London: Pharmaceutical Press; 2014. p. 432-4.

19. Gadhekar R, Saurabh MK, Thakur GS, Saurabh A. study of formulation, characterisation and wound healing potential of transdrmal patchs curcumin. Asian J Pharm Clin Res 2012;5:225-30.

20. Giri TK, Thakur A, Alexander A, Badwaik H, Tripathi DK. Modified chitosan hydrogels as drug delivery and tissue engineering system, present status and aplication. Acta Pharm Silaica B 2012;2:439-49.

21. Goci EN, Haloci EN, Xhulaj SK, Malaj LE. Formulation and in vitro evaluation of diclofenac sodium gel. Int J Pharm Pharm Sci 2014;6:259-61.

22. Goswami DS, Uppad N, Gloyal S, Mechta N, Gupta AK. Permeation enhancer for transdermal drug delivery from natural and synthetic sources. J Biomed Pharm Res 2013;2:19-29.

23. Gupta JR, Irchiya R, Garud N, Priyanka T. Formulation evaluation of matrix type transdermal patchs of glibenclamide. Int J Pharm Sci Drug Res 2011;1:46-50.

24. Jadhav RT, Kasture PV, Gattani SG, Surana SJ. Formulation and evaluation of transdermal films of diclofenac sodium. Int J Pharm Tech Res 2009;1:1507-11.

25. Jahan L, Ferdaus R, Shabeen SM, Sultan MZ, Mazid MA. In vitro transdermal delivery of metformin from HPMC/PVA based transdermal drug delivery patch et different ph. J Sci Res 2011;3:651-7.

26. Jatav VS, Jitentra S, Rakesh KJ, Sharma K, Ravindra PS. Recent advances in development of transdermal patchs. Pharmacopore 2011;2:287-97.

27. Liang S, Liu L, Huang Q, Yam KL, Preparation of single or double network chitosan/poly(Vinyl Alcohol) gel film through selectively cross-linking method. Carbohydrate Polym 2009;77:718-24

28. Kouchak M, Ameri A, Naseri B, Boldag SK. Chitosan and polyvinyl alcohol composite film containing nitrofurazone, preparation and evaluation. J Basic Med Sci 2014;17:14-20.

29. Malji P, Gandhi A, Jena S, Maji N. Preparation and characterization of maleic anhydride cross linked chitosan polyvinil alcohol hydrogel matrix transdermal patch. J Pharm Sci Tech 2013;2:62-7.

30. Patel H, Bhimani B, Patel G, Transdermal drug delivery system. as prominent dosage form for the highly liphophilic drugs. Int J Pharm Biosci 2012;1:42-65

31. Patil SS, Gupta RM, Gupta KS, Doddayya H. Formulation and characterization of tpp cross-linked chitosan microspheres loaded with lornoxicam. J Biomed Pharm Res 2014;3:51-8.

32. Pouranvari S, Ebrahimi F, Javadi G, Maddah B. Chemical cross-linking of chitosan/polyvinyl alcohol electrospun nanofibers. Original Sci Artcle 2016;50:663.

33. Raj AR, Formulation evaluation and in vitro permiation studyes of transdermal nifedipine from matrix type patch. Int J Pharm Pharm Sci 2013;6:185-8

34. Raza R, Mittal A, Kumar P, Alam S, Prakash S, Chauhan N. Approach and Evaluation Of Transdermal Drug Delivery System. Int J Dev Res 2015;7:222-33.

35. Rowe RC, Sheskey PJ, Owen SC. Hanbook of Pharmaceutical Excipients. $5^{\text {th }}$ ed. London: The Pharmaceutical Press; 2006. p. 217-611.

36. Sachan R, Bajpai M. Transdermal drug delivery system a review. Int $J$ Dev Pharm Life Sci 2013;3:748-65.

37. Saroha K, Yadav B, Sharma, B. Transdermal patc, a discrete dosage form. Int J Curr Pharm Res 2011;3:98-108.

38. Setyawan EI. Pengaruh Kombinasi HPMC dan MC Terhadap Karakter Fisik dan Pelepasan Ketopropen dari Matrik patch Transdermal. Yogyakarta: Tesis Universitas Gajah Mada; 2013. p. 73.

39. Sharma K, Singh V, Arora A. Natural biodegradable polymer as matrics in transdermal drug delivery. Int J Drug Dev Res 2011;3:85-103.

40. Sherwood L. Human Physiology, From Cells to Systems. $6^{\text {th }}$ ed. Belmont, CA: Cencage Learning; 2012. p. 485-6.

41. Ng SF, Rouse JJ, Sanderson FD, Meidan V, Eccleston GM. Validation of static franz diffusion cell system for in vitro permeation studies. AAPS Pharm Sci Tech 2010;2:1432-41.

42. Singh I, Sri P. Percutaneus penetration enchanment in transdermal drug delivery. Asian J Pharm 2010;4:92-101

43. Sinko PJ. Martin's Physical Pharmacy and Sciences. $6^{\text {th }}$ ed. Philadelphia: Lippincot William, Philadelphia Pharmaceutical; 2016. p. 223. 
44. Soujanya C, Lakshmi Satya B, Lokesh Reddy M, Manogna K, Ravi Prakash P, Ramesh A. Formulation and in vitro and in vivo evaluation of transdermal patchs of lornoxican using natural permeation enhancers. Int J Pharm Pharm Sci 2014;6:282-6.

45. Subrata M, Kumar PD, Mukherjee B, Sengupta S, Pattnaik S, Chakraborty S. Optimization of in-vitro permeation pattern of ketorolac tromethamine transdermal patchs. Iran J Pharm Res 2011;10:193-201.

46. The Board of Trustees. United Sates Pharmacopeia. $27^{\text {th }}$ ed. National Formulary Rockville: The Board of Trustees; 2007.

47. Varshosaz J, Karimzadeh S. Develpment of cross-linked chitosan for oral mucosal delivery of lidocain. Res Int Pharm Sci 2007;2:43-52.

48. Wasitaatmaja SM, Penuntun Ilmu Kosmetik dan Medik. Indonesia: Penerbit Universitas Jakarta; 1997. p. 3-5.
49. Watkinson AC. Transdermal and topical drug delivery today, Transdermal and Topical Drug Delivery. Principles and Practice. Hoboken, NJ, USA: John Wiley Sons Inc.; 2012. p. 357-66.

50. Wester RC, Maibach HI, Regional Variation in Percutaneus Absorption Drugs, Cosmetic, Mechanism, Methodology. New York: Marcel Dekker; 1997. p. 107.

51. Wise DL. Handbook of Pharmaceutical Controlled Release Technology. New York: Marcell Dekker; 2000. p. 321.

52. Wang Q, Du Y, Fan L. Properties of chitosan/poly(vinyl alcohol) film for drug controlled release. J Appl Polim Sci 2004;96:808-13.

53. Xiong Y, Liu QL, Zhang QG, Zhu AM. Synthesis and characterization of cross-linked quaternized poly(vinyl alcohol)/chitosan composite anion exchange membranes for fuel cells. J Power Sour 2008;183:447-53. 